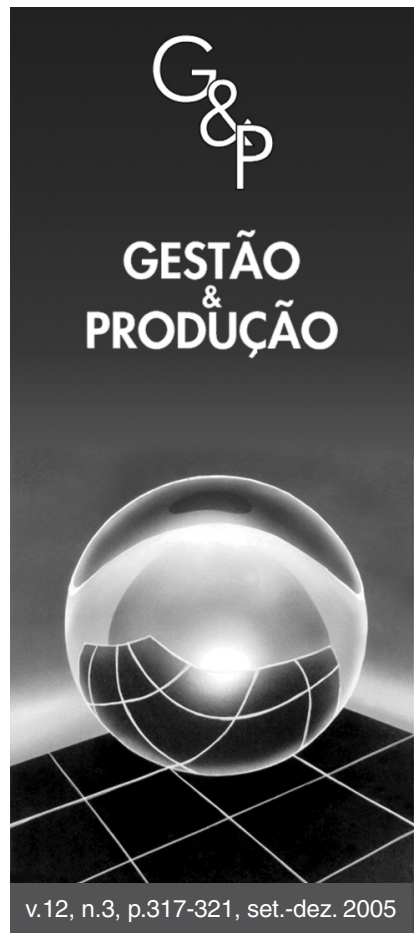

\title{
CHANGING AGENDAS FOR OPERATIONS MANAGEMENT
}

\author{
Martin K. Starr
}

Crummer Graduate School of Business, Rollins College, Winter Park, Florida 32789, USA,

e-mail: mstarr@rollins.edu

Abstract

Looking at past and present developments in the production and operations management (P/OM) field over time provides insight about where future directions may have us heading. Being in the field, whether academic or practitioner, or both, the sense of direction may seem less important than the ways in which one is involved. Cruise directors have been known to say, it is not where you are going; it is how you get there. In this brief analysis, goals and objectives are equivalent to destinations; alternatively, methods, plans, and agendas are the means of getting there.

Keywords: operations management, service operations, manufacturing operations, research trends.

\section{Past}

Even in the days of Frederick W. Taylor (father of Scientific Management; 1856-1915) and Henry L. Gantt (creator of Gantt Charts; 1861-1919) there never was one fixed plan or a single agenda that everyone acknowledged for the proper development of production and operations management $(\mathrm{P} / \mathrm{OM})$. However, there was general agreement among those in the field (practitioners and consultants) about desirable goals and realistic objectives. The consensus goals were: 1) to make operations ever more cost efficient; 2) to increase productivity; and 3) to improve quality, including being fast and timely. Also, there was general concurrence that process mastery was the required means to the desired ends.

Well before the middle-ages, process mastery required understanding materials, and knowing how to develop and use tools and machines to shape materials. A different but compelling issue dealt with plans to utilize water, steam, and electricity to provide power to operate factory machinery. In addition to these obvious programs there was a hidden, key agenda to attain the ability to manufacture goods using interchangeable parts (IP).
The idea for using interchangeable parts may have arisen as early as the Guild Halls of the 1500's. However, for centuries, no one felt that IP could be attained because art rather than science dominated fabrication. It is not surprising that the Industrial Revolution in England acted as a trigger to the quest for IP. In 1782, James Watt had developed the rotary steam engine which was able to drive factory machines. Interchangeable parts needed a host of machine-tool inventions. They were starting to be developed in the last half of the $18^{\text {th }}$ Century. What was missing was underlying theory without which IP could not become a practical methodology. The theory of what makes parts interchangeable would provide the means to the end of exceedingly higher productivity.

Benjamin Franklin, as the U.S.A. ambassador to France, heard about a French gunsmith who was developing IP manufacturing methods. Franklin told Thomas Jefferson about the concept being developed by Honore Le Blanc in Paris. Jefferson found out that Eli Whitney, the American inventor of the cotton gin, who ran a gun factory in Connecticut, was simultaneously experimenting with IP. 
It was difficult to separate cotton fibers from the seeds and hulls of green seed cotton (the only crop that would grow in the U.S.A.). Whitney's gin (from engine) revolutionized the value of the cotton crop in America. His machine was "pirated without a qualm" before he could obtain a patent. See the discussion by The Eli Whitney Museum at http://www.eliwhitney.org/inventor.htm. It is not an accident that Le Blanc and Whitney were trying to develop IP at the same time. IP was a concept whose time was soon to come. There was a convergence of knowledge that was occurring. Although Whitney was utterly dismayed by the loss of revenues from his cotton gin, he believed that creating an IP factory was a challenge worthy of his skills as an inventor. Whitney assumed, and so-stated, that quality muskets could be produced in great numbers, at low cost by using interchangeable parts. That possibility commanded everyone's attention.

Jefferson wrote Virginia governor James Monroe who helped Eli Whitney (1765-1825) get a contract to fabricate 10,000 muskets in 1798 . The contract required that each of fifty musket components have 10,000 interchangeable parts. Completing the contract required ten years because a new type of factory had to be developed to convert the idea of IP into a reality. Each part brought its own challenges for developing cutting and holding tools. Achievements were obtained slowly. Many parts could not pass the IP test (substitution at random) and required customization. The theory behind the creation of interchangeable parts had yet to be discovered. The benefit of rapid production throughput was more than a century away. Henry Ford accomplished sequenced assembly of the Model T in the years between 1908 and 1914. At that time, only part of the IP concept was understood. Nevertheless, it was the engineering feat that Eli Whitney had been striving to achieve.

While Whitney understood the benefits of parts interchangeability he did not know that a statistical explanation of manufacturing dimensional variability was at the heart of the matter. Whitney in 1798 could not know that a critical theory of manufacturing tolerances would be derived from the work of statisticians over 100 years later. Spanning all these years, the destination was unchanged. The means of getting to the destination remained the problem. Henry Ford achieved IP without fully understanding the underlying theory.

Based on statistical inference, William S. Gossett (1876-1937) created a test to determine if a calculated mean and standard deviation, using a "small" sample, can estimate the likely range of the "real" mean and standard deviation based on a "large" sample. Gossett was an employee of Guinness Brewery which did not permit publication by employees. As a result, Gossett's famous t-test appeared in Karl Pearson's Journal, Biometrika, under the pseudonym of Student in 1908.
Gossett's work inspired Walter A. Shewhart (father of statistical quality control (SQC); 1891-1967) to develop quality control theory relating assignable causes and chance causes of variation. Using the basic concepts of the t-test, Walter Shewhart developed the theory of statistical quality control. Shewhart's theory was critical to understanding the variability of dimensions of parts coming from the same machine. Shewhart's invention of SQC established the theoretical foundations of interchangeable parts.

Less than 200 years after Eli Whitney struggled to make muskets using IP, another new challenge confronted the field of production and operations management. An everlarger part of many developed nations' economies was based on providing services that were formerly accomplished by family barter and do-it-yourself activities. Before 1940, many people grew their own food, or bought it from local farm stands. Most families cooked meals at home. They did their own laundry, tended their stoves and did their own repairs. The amounts that families paid for healthcare, education, entertainment, transportation, insurance, banking and investments, were minimal. The service sector was beset with inefficiencies. As it became an ever-larger part of the economy, the goals for improving productivity were similar to those in manufacturing years before. However, the means of achieving those goals were unfamiliar and obscured.

There were similarities between manufacturing and services (Levitt, 1972). Many forces account for the growth of the service sector. Not the least of these was the fact that both parents became wage-earners. When service industries grew to become a large part of the gross domestic product, it became apparent that the benefits $\mathrm{P} /$ OM had brought to manufacturing could (and should) be applied to services. Sloppy supply chains abounded in service industries, but not so in manufacturing which had learned many important lessons from military logistics. Services have improved significantly since Levitt (1972), but enormous opportunities and challenges remain at the present time.

\section{Present}

Inadequacies of the health care supply chain in the U.S.A. were estimated to waste over 11 billion dollars per year (EHCR, 1996). As of this writing, nothing significant has been done to alleviate waste in the healthcare supply chain. Bankruptcies in the U.S.A. airline industry provide another good example of irrational service-sector business models that prevail without correction. Timothy R. Coleman, Senior Managing Director of the Blackstone Group (http://www.blackstone.com) said that the "airline business is the most structurally flawed business model in the world" (Tatge, 2005). 
The supply chain for services can differ for each service application and for demographic segments within each of the service applications. The segmentation of the service supply chain means that what is good for one segment is not good for all segments. Strategy and policy must deal with multiplicity of tastes and a single overriding prescription will not optimize the system. There is no dispute about observations by Levitt (1972), but there is far more variety of a personal kind in service markets than in manufacturing goods for retail. Putting services in a proper perspective for the decade ahead, KM World News (2005) states "most one-size-fits-all consumer search engines are not appropriate for businesses."

As with manufacturing, there is agreement among those in the field that goals should include: 1) making operations more cost efficient; 2) increasing productivity, as well as; and 3) maintaining or improving quality, including timeliness. For services, as compared to goods, points 1 and 2 are more beholden to point 3 , that is, maintaining or improving quality across a broad spectrum of personal choices. Quality is a sum of consumer perceptions. Customers' first choice preferences for services are greatly varied. This is true, not only with dimensions such as specific kind of service rendered, kindness, attentiveness, and competence, but also the chemistry of contact between the servers and the serviced.

Getting high marks for service quality requires satisfying many participants in highly segmented market places. Even more demanding, in each segment, individuals can have drastically diverse criteria for judging excellence. For manufacturing, quality is achieved when interchangeable parts fall within tolerances. Parts are so similar that they are entirely substitutable in assembly. The opposite holds for services. Customized service, at its extreme, means that the unique characteristics and desires of every individual are recognized and satisfied. Thus, the basis of service of the highest quality is diametrically opposite the basis of manufacturing of the highest quality.

The service sector has a hidden agenda not unlike that of interchangeable parts which drove manufacturing methodology for many years. The service sector agenda strives to maximize variety while the manufacturing agenda strives to minimize variety. Marketing prefers variety in both cases. Variety in goods can be enhanced if interchangeable parts can be put together to form many different products. This is known as modular product design. It continues to be explored by various organizations as a means of promoting customer satisfaction based on variety in a cost effective way.

Modular product design (MPD) can be applied to services as well as manufacturing. It may well be that modular service products are equivalent to IP achieve- ments in manufacturing. Unique service products can be assembled into kits as easily as manufactured goods that have been pre-planned to work together. For example, a modular combination for an auto might consist of blue chassis, leather seats, GPS, DVD, six cylinder engine, white-walled tires, etc., A modular combination for a brokerage account might consist of tax-exempt money market, international mutual fund, regular checking account, credit card, unified reporting system, etc.

Modular product design is a means of gratifying consumers' requests for customized service selection (CSS). To an important extent, MPD is an extension of the IP concept from parts to products. It is applicable to a variety of services including ever-present IT (Information Technology) applications. Combinations of program modules have been used for a long time. For example, calculations of Net Present Value, Return on Investment, etc. do not have to be rewritten each time that a spreadsheet is designed for a specific application. This is often called modular programming. It has also been known by other names such as structured programming, procedural programming, and object-oriented programming.

Greater understanding of modular production is required to fulfill the great potential of MPD as a means of satisfying customers' requests for services. A respectable example of this scenario is provided by restaurants which have extensive menus of meals (formed by combinations of ingredients). Popularity is based on assortments of choices that are fairly priced for the food qualities served. On-line education is another reasonable example of a growing market based on modularity. Students can exercise a high degree of choice with respect to curricula, course sequences, number of courses, etc. Another rich example is provided by supermarkets. Compare them to the old general store where one brand of each staple item may be available. In many parts of the world today, bulk products such as tubs of butter and barrels of pickles are unbranded local products.

No matter how many good examples are given of service product modularity, there is a predominant failure to provide customized individuality in service products. Surveys show that customer dissatisfaction is high in many retail stores, with most airlines, all car rental agencies, some banks, most stock brokers, many hotels, some resorts, many cruise ships, etc. Lack of customized individuality in service products is a matter of concern but also an incredible opportunity waiting to be addressed.

Interactions between supply chain management and the variety of services that can be offered stands out as an agenda item that needs to be properly addressed at the present time. In particular, services to promote safety and security turn out to be a weak link in the scenarios of future events. $\mathrm{P} / \mathrm{OM}$ needs to address a number of dan- 
gerous scenarios which did not exist in the past. They began to exist in the present and must be eliminated in the future.

\section{Future}

For those in the P/OM field, new and pressing problems have arisen since November 9, 1989. That is when the Berlin Wall came down and the "Cold War" ended. It was the start of a geopolitical upheaval that unexpectedly unleashed potent forces. This outcome was counter-intuitive to many scholars. Fukuyama (1992) argued that liberal democracy would now become the only prevailing institutional form of government. The End of History signified a lessening of strife and confrontation. Economic competition was the logical replacement for arms rivalry.

Surprising those who believed that calm times had now arrived, grave historic challenges began to surface in the "post cold war" freer-world. Opposition grew to global economic development. The belief that everyone supported technological progress turned out to be naïve. In this polarized situation, one side saw great benefits from big airplanes, cell phones, and global communications. The other side saw technology as weapons to destroy or subjugate everyone different from themselves.

The cold war had pitted two blocks of nations against each other in a military stand-off. The new confrontation was a split between ideologies, not nations. Military solutions are playing a part, but the bigger picture is homeland security against terrorism. In homeland security, good production and operations management thinking has become essential.

Technology that could turn planes into missiles did not exist fifty years ago. The Boeing 707 was introduced as the first commercial jet plane in 1958. In 2001, suicide hijackers were able to destroy the World Trade Center using the technology of the most advanced commercial jets.

The dynamics of world opinion have changed since the effects of suicide bombings are instantly communicated by telecommunication technology that reaches around the globe. In other words, the unintended consequences of new technology have provided terrorists with destructive capabilities never dreamed of before and the means to terrorize their target audiences with vivid media coverage of catastrophes.

Any geographic area that receives television (and radio) signals is now part of a targeted realm of the global village. Access increased tremendously once satellites could reach places where communications were formerly impossible, or not economically justified. The modus operandi of terrorism is to use the media to create paralyzing fears in chosen populations that result in severe damage to economic well-being.
Apart from airplanes aimed at structures, new explosive-making technologies allowed powerful car bombs to be built by novices who took their destructive recipes from the Internet. A suicide bomber can wear a concealed belt with enough blasting power to destroy everything in a cavernous hotel lobby.

In addition to bombs, there are bioterrorism threats. Anthrax powder and ricin toxin have been used against the public in diverse countries. The U.S.A. Centers for Disease Control provide emergency preparedness information about 47 "bioterrorism agents/diseases" at one of their websites: http://www.bt.cdc.gov/agent/agentlist. asp. These include air, water and food safety concerns. Nuclear-based terror risks are covered in detail at: http:// www.nci.org/nci-nt.htm.

At these websites, the general focus is on what to do after an act of terror. For production and operations managers, repair and restoration is the last resort. The key to good process management is detection of problems and prevention of damage before it occurs. Proper P/OM utilizes predictive/preventive maintenance to avoid the onslaught of breakdowns and catastrophes.

One of the central objectives of terrorists is to create fear. Both of two conditions are required to accomplish this objective. First is the horrific act of terror, and second, is the worldwide publicity to inform everyone of the feat. Since there is no appetite to censor the press because that violates fundamental human rights, it is the first condition that must be controlled to eliminate terrorism as much as possible.

$\mathrm{P} / \mathrm{OM}$ must accept the responsibility for systematically dealing with terrorism. Marketing and finance cannot do it. This does not represent a new set of goals or destinations for P/OM. The goals (low cost, high productivity, and quality) remain the same but the agenda concerning how to achieve them is markedly different. Terrorism altered the balance between so-called normal accidents (Perrow, 1984) and malicious catastrophes from sabotage.

Quality goals always include safety and security. Dangerous machines are not tolerated; chemical explosions are eliminated; accident records are posted on the walls for all to note decreasing numbers. Security against theft and vandalism has always been part of the P/OM job. It has taken on increasing importance. It must be elevated above all other company concerns in the future.

Detection and prevention are part of the P/OM toolkit. But $\mathrm{P} / \mathrm{OM}$ is not used to dealing on a national or international stage which is absolutely essential now. Safety of the ports must be viewed with a systems-eye that recognizes the need to know what is flowing in and out at all times. Security of all air travel as well as railroad and ship travel is a P/OM capability. Protection of the supply chain against vulnerabilities has previously been focused 
on normal accidents. Now it must include malicious and purposeful sabotage. Technology teamed with methodology must be enlisted to counter and control the unintended consequences of technology employed in various perverse ways.

We may need to develop new formats to enable P/OM to handle international cooperative challenges. Appropriate organizations for International Operations Management (I/OM) would function across borders and share international data bases. Identification of people and cargo will play a critical role in spotting anomalies that signal the out-of control point that demands investigation. The research agenda is fascinating and compelling.

National concerns about air, water and food may profit from a governmental agency that perhaps could be known as PS/OM (Public Systems Operations Management). It is time to bring into existence such an organization to stop carnage on the highway systems of America and the world. In the process of developing technology and methodology to insure safety and security, P/OM can turn its ability to issues such as accident control on the highways. In the year 2004, in the U.S.A., 42,636 people were killed in automobile accidents; 2,788,000 people were injured; 4,281,000 accidents involved property damage.

The invoice for death and destruction is high enough to fund research to end the massacre and improve the safety of travel. An era of inventions to promote safety and security is needed similar to that which created the methodology-technology-information network upon which our present-day society is based.

\section{Bibliographical References}

EHCR. Efficient Healthcare Consumer Response: Improving the Efficiency of the Healthcare Supply Chain. Chicago: American Society for Healthcare Materials Management, 1996.

FUKUYAMA, F. The End of History. New York, Free Press, 1992.

KM WORLD. Choosing a Consumer Search Engine for your Business Search. KM World News, November 14, 2005. Available at URL:<http://www.kmworld.com/NewsLetters/>. Accesso: nov, 2005.
LEVITT, T. Production-line approach to services. Harvard Business Review, v. 50, n. 5, p. 41-50, sept./oct. 1972.

PERROW, C. Normal Accidents: Living with High-Risk Technologies. New York, NY, Basic Books, 1984.

TATGE, M. Costs Lift off at Low-Cost Airlines. Forbes, Oct. 24, 2005. Avaialable at URL: <http://www.forbes. com/business/2005/10/24/southwest-jetblue-bankruptcies-cz_mt_1024airlines.html). Access: nov, 2005.

\section{MUDANDO A AGENDA PARA GESTÃO DE OPERAÇÕES}

\section{Resumo}

Observar, ao longo do tempo, os desenvolvimentos passados e presentes no campo de conhecimento de P/OM (Administração de Produção/Operações) provê indícios sobre para onde o direcionamento futuro pode nos levar. Estando na área, seja como acadêmicos ou praticantes, ou ambos, o senso de direção pode parecer menos importante do que as formas segundo as quais se está envolvido com o assunto. Capitães de navio são conhecidos pela máxima: não se trata de para onde se está indo; a questão é como se chega lá. Nesta breve análise, metas e objetivos são equivalentes a destinos; alternativamente, métodos, planos e agendas são os meios de se chegar lá.

Palavras-chave: gestão de operações, manufatura, serviços, tendências para pesquisa. 